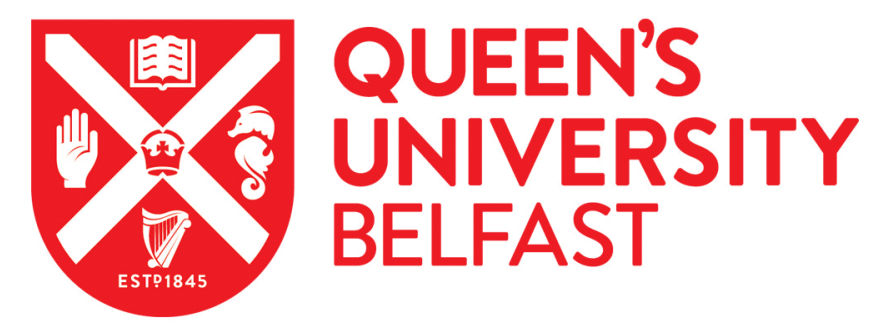

\title{
Comparing British and American conservatisms through the prism of African development
}

Andreasson, S. (2017). Comparing British and American conservatisms through the prism of African development. Commonwealth \& Comparative Politics, 55(4), 471-488.

https://doi.org/10.1080/14662043.2017.1300845

\section{Published in:}

Commonwealth \& Comparative Politics

\section{Document Version:}

Peer reviewed version

Queen's University Belfast - Research Portal:

Link to publication record in Queen's University Belfast Research Portal

Publisher rights

(c) 2017 Informa UK Limited, trading as Taylor \& Francis Group.

This work is made available online in accordance with the publisher's policies. Please refer to any applicable terms of use of the publisher.

\section{General rights}

Copyright for the publications made accessible via the Queen's University Belfast Research Portal is retained by the author(s) and / or other copyright owners and it is a condition of accessing these publications that users recognise and abide by the legal requirements associated with these rights.

Take down policy

The Research Portal is Queen's institutional repository that provides access to Queen's research output. Every effort has been made to ensure that content in the Research Portal does not infringe any person's rights, or applicable UK laws. If you discover content in the Research Portal that you believe breaches copyright or violates any law, please contact openaccess@qub.ac.uk. 


\title{
Comparing British and American conservatisms \\ through the prism of African development
}

\author{
forthcoming in Commonwealth \& Comparative Politics (2017)
}

\author{
Dr Stefan Andreasson \\ School of History, Anthropology, Philosophy and Politics, Queen's University Belfast \\ s.andreasson@qub.ac.uk
}

\begin{abstract}
Conservatism and conservative party politics in Britain and America is associated with neocolonial attitudes, including pursuit of national interests ahead of post-colonial development. Based on interviews conducted in Washington and London with actors involved with African development, this article examines comparative shifts in conservatives' engagements from the late Cold War era to the G. W. Bush and Cameron governments. Greater ideological heterogeneity and distinctiveness among American conservative interests groups, combined with a bureaucratic environment in the US allowing more direct channels for ideological input into policy, results in a more clearly conservative stamp on Africa policy in the US than in Britain where ideological lines on development have become more blurred since the 1997 New Labour election victory and creation of the Department for International Development.
\end{abstract}

This work was supported by a British Academy Small Research Grant, 'Anglo-American Conservatism and 21st Century African Development'.

Key words: Conservatism, Ideology, Political Parties, Britain, USA, Development, Africa

Word count: 7,634 


\section{Comparing British and American conservatisms \\ through the prism of African development}

And what should they know of England who only England know?

-- Rudyard Kipling, The English Flag (1891)

\section{Introduction: who cares about Africa?}

Kipling's lament, about the parochialism of his fellow Englishmen hints at an important insight that underpins the arguments in this article. Only by considering a particular phenomenon in a wider, comparative, context can it be properly understood. ${ }^{1}$ As will be argued, it is possible to discern distinct types of conservatism, including their evolution across time and space, by examining them in a context beyond the immediate one in which they are most commonly manifested and considered. In terms of British and American conservatism, such consideration takes place primarily in the literature on political ideologies and the history of political thought (Oakeshott, 1962; O’Sullivan, 1976; Quinton, 1978; Honderich, 1980; Kirk, 1995; Nash, 2006).

Considering how British and American conservatives, including the Conservative and Republican parties that have channelled conservative ideology in these two countries into party politics and government policy ${ }^{2}$, have perceived their respective countries' relations with Africa and have consequently engaged with the continent in specific matters of policy is instructive for two key reasons. Firstly it makes it possible to understand how and why conservatives and conservative governments have shaped policies towards Africa, with all the consequences that foreign policies of two of the region's most important external actors have inevitably had. Secondly it sheds light on conservatism as an ideology, including how conservatives as political actors differ from each other in Britain and America and how these differences have evolved over time. That ideology influences politics tends to be taken as axiomatic. Examining the link between conservatism and policies 
relating to African development as they have evolved over time provides an insight into the validity of that assumption.

There is a long-standing association of conservatism and of conservative party politics in both Britain and the US with neo-colonial attitudes towards Africa and other developing regions, and with a preference for pursuing strategic and economic national interests ahead of policies aimed primarily at addressing developmental needs of African countries (e.g., Bull, 1982; Coker, 1983; Sharp et al., 2010; Heppell \& Lightfoot, 2102). Such associations generally imply that there is less to discover in the attitudes and strategies of conservative parties and interests groups that is of value for understanding how development can best be promoted. As a consequence, a wealth of literature on relations between the West and Africa in the context of promoting development has prioritized and been driven by the assumptions of political parties and actors, non-governmental organizations, social movements and the like on the liberal/Left side of the political spectrum rather than on their counterparts on the conservative/Right (for examples of this critical tradition, see Amin, 1972; Sandbrook, 1985; Bond, 2006).

But conservative values and ideology, notably in their 'neo-liberal' shape constituting a direct challenge to Keynesian and neo-Marxist scholarship, have had a significant impact on both British and American thinking about economic relations with Africa including developmental policies (for examples of this 'neo-liberal' shift in thinking about development in Africa, see Owusu, 2003; for a historical perspective, see also Duignan \& Gann, 1975). Moreover, conservative values and policies have changed over time and have evolved in distinct ways in Britain as compared to the US, even if these two countries share an Anglophone heritage of conservative values and political ideology (Preece, 1980; Andreasson, 2011a, 2014). Given substantial periods of government in the post-World War II era by the Conservative Party in Britain and the Republican Party in the US (40 and 45 years, respectively) the nature of conservatism and conservative politics in these two countries is significant and therefore worthy of a comparative investigation. ${ }^{3}$ 
Based on interviews conducted in Washington and London with policymakers and related actors involved in shaping and engaging with a range of developmental issues in Africa, including key Conservative and Republican party members and officials, ${ }^{4}$ the article examines comparative shifts in conservative engagement from the late Cold War era of the Thatcher and Reagan governments to the twenty-first century approaches of the G. W. Bush (henceforth referred to as Bush) and Cameron governments. ${ }^{5}$ This comparative examination derives from two sets of competing explanations for the role of ideological and political forces in driving engagement with Africa. One suggests that 'caring' about Africa is the preserve of progressives on the Left, with conservatives mainly defending a status quo that is largely inimical to Africa's developmental aspirations. The other holds that Africa is at best a marginal concern for Western powers, and as such there is little need for conservatives and the Left to differentiate their foreign policies in this regard.

In this article, a different emphasis and explanation is proposed which recognises some significant differences among conservatives across countries. The hypothesis is that a greater ideological heterogeneity and distinctiveness among American conservative interests groups than among their British counterparts, combined with a bureaucratic environment in the US in which there are more direct channels for ideological input into policy, results in a more clearly conservative stamp on Africa policy in the US than has been the case in Britain where ideological lines on development have become more blurred since the 1997 New Labour election victory and subsequent creation of the Department for International Development (DFID). Distinct approaches and trajectories are furthermore reflected in a diverse number of issue areas and can be observed in a wide range of developments, for instance in the competition for influence in Africa's important energy markets in which their American and British energy companies have long-standing interests (Frynas \& Paulo, 2007; Andreasson, 2015).

The following sections outline instructive instances of how American and British conservatives have engaged with development in Africa and how such engagement evolves from 
the Cold War into the twenty-first century. While the article deals foremost with the agency of British and American actors, and the ideological context shaping attitudes and policies in their respective countries, it thereby also provides an understanding the opportunities and constraints faced by African government officials and other significant actors in dealing with this influential ideological segment of government and policymaking in what are two of the external powers most extensively involved in African affairs.

\section{From Cold War to moral crusade in American conservatism}

The end of the Cold War and the subsequent emergence of American triumphalism in the 1990s triggered what Krauthammer (1990), in an address to a 1990 Conservative Leadership Conference in Washington, famously described as America's unipolar moment. It helped liberate American policymakers generally, and conservative ones in particular, from the straightjacket of a preoccupation with the strategic imperatives of Cold War thinking (Ikenberry, 2004; for a critical view on implications for Africa, see also Moss, 1995). This was a significant development in America's international relations, although Walt (2000) demonstrates that even the ostensibly liberal Democratic administration of President Bill Clinton remained wedded to central tenets of Realpolitik. It became possible, however modestly in the greater scheme of US foreign policy priorities, to address more explicitly humanitarian and developmental issues. These issues would, in the African context, inevitably end up revolving around the widespread poverty and underdevelopment that has dominated the Western image of Africa - in particular since the Ethiopian famine of the 1980s which gave rise to the Live Aid phenomenon as a totem of Western concern and obligation vis-à-vis the continent (Dunn, 2004; de Waal, 2006; Busby, 2007). Such developments flow from a well-established view on Africa's underdevelopment and the need for external (Western) actors to resolve the continent's problems (Andreasson, 2005).

This new environment also made it possible for American conservatives, and the Republican Party, to contest what had normally been considered Democratic Party ground, even if that 
contestation would be slow in the making. Goldstein and Moss (2005, p. 1289) contrast Clinton's celebrated visit to Africa in 1998 with the decidedly more reserved and sceptical reception of President Bush's visit to the continent, the first ever by a sitting Republican president, in 2003 as symptomatic of the popular perception that 'Democrats care more than Republicans about [Africa]'. This perception, that Africa and the interests of its peoples are better served by Democratic governments than by Republican ones, is deeply rooted. It was, after all, President John F. Kennedy who founded the US Agency for International Development (USAID), and President Jimmy Carter who prioritised human rights, and later also charity work, in Africa. By contrast, the prolific and combative Republican Senator Jesse Helms, a former Chairman of the Senate Foreign Relations Committee, infamously likened foreign aid, a key instrument in US-African relations, to 'money down a rat hole' (Goldstein \& Moss, 2005, p. 1289).

But the post-Cold War environment facilitated the mobilization of social forces that had previously played a less prominent role in shaping US foreign policy (Martin, 1999). America's evangelical Christians, who had asserted their political influence with increasing effectiveness since the rise of the Moral Majority in the 1980 and then with help of the Conservative Revolution in the 1990s, were well positioned to embrace and play an important role in this new stage in American relations with Africa (Dyer, 2014). Having had little interest in the continent previously outside a history of missionary activities, the new brand of 'compassionate conservatism' as it came to be known with the arrival of Bush's presidency, saw religious conservatives take an interest in issues ranging from the HIV/AIDS pandemic ravaging Africa (including issues of sexual morality) to the plight of Christians in the Sudan, including what were on the whole misrepresentations of the Darfur conflict (Huliaras, 2008/9). Indeed, Huliaras argues that the approximately quarter of the US population that consists of evangelical Christians 'were once considered America's staunchest isolationists ... [but] have come to play a significant role in the making of US foreign policy, especially with respect to developing countries' (Huliaras, 2008/9, p. 161). 
This type of engagement has also manifested itself at the centre of political power in Washington. Joel Starr, former Deputy Assistant Secretary for House Affairs and foreign relations advisor to Senator James Inhofe of Oklahoma, notes that the distinctiveness with which conservatives have engaged with Africa is often a matter of personal values and initiatives (interview with author, Washington, September 2011). Starr points to the long-standing involvement of Senator Inhofe as a good example of this type of personal engagement. Known as 'the Senator from Africa' on account of being the senator who has travelled most extensively in Africa in the history of the Senate, it is Inhofe's personal knowledge and values that has shaped his engagement with African policy issues (for a critical view of this engagement, see McGovern, 2012). This, according to Starr, is perhaps not surprising as Oklahoma has the greatest number of missionaries per capita of any US state and therefore this legacy of missionary zeal and the fact that many religious organizations are based in Oklahoma has facilitated a more extensive engagement with Africa (interview with author, Washington, September 2011).

While bipartisanship has regularly characterised US foreign policy in relation to Africa there was nevertheless a qualitatively new step in conservative engagement that was made possible by the Republican Party winning the presidency in 2000. Todd Moss, Senior Fellow of the Center for Global Development in Washington and a former Deputy Assistant Secretary in the Bureau of African Affairs at the U.S. Department of State in the Bush administration, notes that when it comes to African affairs, congressional Republicans have had a more organised constituency which has therefore been more readily pro-active across a range of policy initiatives than have the Democrats who are otherwise more generally identified with being 'pro-African' (interview with author, Washington, September 2011). Bush had been narrowly elected in 2000 on the promise of pursuing a domestic agenda of reviving conservatism in economic and social policymaking. Following the 9/11 terror attacks his presidency became destined to embrace a distinctly and previously unanticipated international dimension, most notably by prosecuting the 'War on Terror', and his many supporters in the evangelical community came to cast their gaze beyond the country's borders 
too (Burkhalter, 2004; Huliaras, 2008/9; on the role of evangelicals in international development prior to the Bush presidency, see Hofer, 2003). Mark Green, President of the International Republican Institute and a former Ambassador to Tanzania who also sits on the Board of the Millennium Challenge Corporation (MCC), is very clear on the importance of the Bush administration for understanding the emerging link between American conservatives and policy on Africa, stating unequivocally that 'US engagement in Africa was changed over night by conservatives through the Bush administration' (interview with author, Washington, September 2011).

For Tom Woods, who served as a Deputy Assistant Secretary of State for Africa under Bush, the president's professed Christianity and ability to link his politics to the values and concerns of America's evangelicals was 'very fundamental' to the shift in how conservatives viewed Africa, drawing on and deriving force from the evangelical Christian view that Americans have a moral obligation to assist those in need as a reflection of their faith. This entails saving souls, but also catering to human needs including food, health and security. There was, according to Woods, a movement underfoot before Bush arrived in Washington, but in it he found a centre of gravity and an effective constituency to tap into. '[I]t made him bullet proof, [because] what Republican could [otherwise] come in, in the tradition of Jesse Helms in the 1980s and 1990s, and say I want to triple aid to Africa?' (interview with author, Washington, September 2011). Indeed, in his critical evaluation of the Bush administration's legacy regarding US policy towards Africa, van de Walle (2009, p. 11) concludes that ' $[\mathrm{t}]$ he biggest success of the Bush administration in Africa was to generate substantial increases in aid'.

Chester Crocker, Assistant Secretary of State for African Affairs throughout the Reagan administration, acknowledges that the increasing involvement of evangelicals in the Bush administration is one important reason for understanding the new, and more generous, spending priorities on development in Africa, even if his interpretation is somewhat more cynical regarding motives as compared to those of conservatives who served in the Bush administration. The 
evangelical push became, according to Crocker, a powerful motivating force that Bush 'bought into', knowing that this approach would be popular and unifying including among congressional Democrats generally who 'would not want to argue' with, for instance, the Black Congressional Caucus on matters at the intersection of religiosity and aid to Africa (interview with author, Washington, September 2011).

However, Jendayi Frazer who served as Assistant Secretary of State for African Affairs under Bush and subsequently as his Ambassador to South Africa, is sceptical of the evangelical link to policy and downplays the importance of religious conservatism and Bush's private faith in shaping development policy towards Africa. But like others involved with Africa policy in the Bush administration, she sees its engagement as a culmination of American engagement and compares it favourably with subsequent policy developments in the Obama administration. The Bush era was, according to Frazer, a high water mark of engagement, 'not because it should have been, but because they [the Obama administration] are not doing their job, because [Obama] does not care about Africa' (interview with author, Washington, September 2011). In a subsequent examination of Obama's Africa policy, van de Walle (2015, p. 54) similarly concludes that the optimism about his administration's likelihood of improving relations with Africa 'was always misplaced' and has been 'something of a disappointment'. Frazer argues that Africa policy was driven by President Bush, the former National Security Adviser and then Secretary of State Condoleezza Rice, then Secretary of State Colin Powell, Frazer herself and many others. 'We cannot exaggerate the role of Powell and Rice ... [who were] very supportive of us who worked on Africa. In the Clinton administration, ... you could not get anything up the ladder. [Former Secretary of State] Warren Christopher did not want to hear anything about Africa'. And without Bush's engagement 'we would not have gotten half done'. When administration officials recognised that African development mattered to the president they wanted to do things on Africa, because, as Frazer puts it, 'it matters to their boss' (interview with author, Washington, September 2011). 
Green argues that the Bush administration's increased engagement, as a conservative Republican administration, with African development resulted in 'taking the ideological sting out of the engagement with Africa' and that, as a consequence, 'there has been 'nothing partisan about engagement with Africa' (interview with author, Washington, September 2011). This even though he also voices what was a common concern in the years after the unfolding of the financial crisis of 2007-08, namely that fiscal pressures on the US government and its budgetary allocation might strain the bipartisan coalition on Africa. The notion that bipartisanship has characterised US policy relating to Africa is reinforced by Crocker. He too endorses the view that engagement with Africa became a more bipartisan issue after the Cold War and that the African Growth and Opportunity Act (AGOA) was a good example of this. One result was the emergence during the Bush administration of a sort of 'love-in between the Christian Right and the Black [Congressional] Caucus' that, as outlined by Dietrich (2007) and Hook (2008), produced the HIV/AIDS initiatives that by 2003 became The U.S. President's Emergency Plan for AIDS Relief (PEPFAR). Congress was generally in favour of such an approach, but it took the leadership of Bush and a lot of social conservatives to amass the votes in support... even if, as Crocker goes on to argue, 'frankly I think there are grounds here for questioning what ultimately became the complete distortion of US foreign assistance policy. When fifty per cent of foreign assistance is [allocated to] health, what does that tell you?' (interview with author, Washington, September 2011).

In addition to bipartisanship, Woods suggests that engagement with Africa during the Bush administration also brought about a more pronounced shift in the traditionally paternalist relations between the US and Africa than what had prevailed during the Cold War era: 'The first time I saw that traditional, paternalistic donor-client relationship changing was during the Clinton administration. But the huge shift was during the Bush administration, when behaviour [towards Africa] really begun to change'. According to Woods, 'the Clinton era was [primarily about] rhetoric' and, while rhetoric was important to bring about a shift in relations the more fundamental shift, towards an emphasis on 'shared responsibility' in development matters came with Bush and 
was manifested most clearly in major policy initiatives such as the Millennium Challenge Account (MCA) and PEPFAR (interview with author, Washington, September 2011; cf. Hook, 2008).

What we see in the case of US conservatives and Republicans engaging with Africa in matters of policy is a significant shift towards a more prolific and pro-active approach following the election of Bush in 2000. The end of the Cold War, the rise of Christian conservatives as a significant interest group in shaping US policy on international development including health and less partisanship in policymaking relating to Africa combine to effect this shift in conservative thinking and approach that has come to characterize the US trajectory. In addition, Hook's conclusions about the emergence of the MMC are relevant for understanding the impact of conservative actors on Africa policy more generally:

[Policy] change cannot adequately be explained without reference to the principled and causal beliefs regarding international development that were widely circulated through distinctive societal pathways prior to the [Bush] administration's coming to power. These beliefs, reflecting ideas exogenous to the policy process, were filtered through domestic structures that ... granted the executive branch substantial freedom to embed the beliefs in a new foreign policy program (Hook, 2008, p. 162).

\section{From management of decline to reinvigorating Britain's global role}

In Britain as in the US it is actors on the political Left, such as the Labour Party, the labour unions and non-governmental organizations (NGOs), who have been more readily associated with acknowledging and ostensibly supporting the post-colonial aspirations of African peoples (Gallagher, 2009). The Conservative Party and conservatives generally have been more readily associated with nostalgia for empire and a more unabashed pursuit of British national interest in dealing with the African continent (e.g., White, 2000), including good relations with several of Africa's long-serving 'strongmen'. This assumption about a more comfortable relationship between African strongmen and British conservatives might, in a rather curious way, have been reinforced 
by Zimbabwean President Robert Mugabe's somewhat eccentric endorsement of the Conservatives in the run-up to the 2010 national election in Britain, asserting that '[w]e have always related better with the British through the Conservatives than [through] Labour... Conservatives are bold; Blair and Brown run away when they see me, but not [the Conservatives], they know how to relate to others' (Stratton, 2010).

This despite the fact that it was a Conservative Prime Minister, Harold Macmillan, who in 1960 before the South African Parliament in Cape Town delivered one of the most influential 'postcolonial' speeches by a Western leader - the so-called 'Wind of Change' speech that was critical of the apartheid regime and which acknowledged the inevitable path towards national independence across the colonial world (Ovendale, 1995; Butler \& Stockwell, 2013). To use a rather simplistic analogy that nevertheless captures these ideological distinctions rather well in the British context, these Labourite and Conservative orientations map onto a similar kind of divide that can be observed in, for instance, the ideological orientations of Guardian and Telegraph readers. An internationalist concern with the aspirations of formerly colonised regions that is often explicitly critical of Britain's colonial heritage is characteristic of the former and a rather more positive assessment of British colonial heritage and the elevation of national interest is characteristic of the latter (on the ideological divide in British newspapers generally, see Newton \& Brynin, 2001).

The former Conservative Foreign Secretary Sir Malcolm Rifkind notes that Britain's historical involvement in Africa inevitably means that engagement by British conservatives with the continent in the post-colonial era differs from that of their American counterparts, whose conservatism is also of a rather different type than the British kind (interview with author, London, November 2011; see also Andreasson, 2011a, 2014). Indeed, 'a lot of [British] conservative thinking ... is based on our own history of being an imperial power [as] Africa is not just another part of the world' (interview with author, London, November 2011; see also Horowitz, 1970). Britain's history in Africa is a matter of a 'not so distant past' and therefore the direct involvement of Britain and of British citizens in African affairs makes a big difference in understanding relations 
with the continent today. After all, Africa traditionally had a higher profile in Britain than in the US on account of more extensive family connections, historical and cultural association, as well as a more prolific British African migrant community (interview with author, London, November 2011; for a nuanced analysis of the African diaspora, see Zeleza, 2005).

But Rifkind also echoes the commonly voiced view that, to the extent that the Conservative Party's engagement with Africa has actually shifted under Cameron's leadership, it has to do with a much deeper and broader process of remaking the party following a long period in opposition. He argues that 'lack of success with post-Major leaders' made it necessary to 'rebrand' the party. The brand 'was not healthy', as evidenced by then Conservative Party Chairman Theresa May's comments about the Tories being 'the nasty party'. This problem was, according to Rifkind, mostly a domestic issue but there was 'an overseas element to it as well' in terms of the Tories' perceived nostalgia for Empire. Judgements were made among the party leadership that a Conservative Party wishing to have a stronger moral base, in terms of ethics of politics and government, 'should be not just resigned to, but positively supportive of the needs to eradicate poverty', and that therefore 'international development 'was a crucial area' with which the party ought to engage (interview with author, London, November 2011; see also Heppell \& Lightfoot, 2012, pp. 132 - 33).

The choice of Andrew Mitchell as Secretary of State for International Development (the first Conservative holding the office) was, according to Rifkind, very important in this regard as he was personally vested in these issues, which evolved into a British version of the Bush administration's 'compassionate conservatism'. Rhetoric is easy, but the party 'needed to show [that] they meant it' (interview with author, London, November 2011). Hence the decision (by 2015 enshrined in law) to spend $0.7 \%$ of Gross National Income (GNI) on aid - the first G7 nation to do so - and embarking on some 'remarkable initiatives... in particular for the conservative party'. Prominent among these was Project Umubano, which is run by the Conservative Friends of International Development and involves high-level conservative party members engaging with social development projects in Rwanda, Burundi and Sierra Leone. ${ }^{6}$ According to Rifkind, a 'quite extraordinary' relationship in 
terms of Conservative Party history. While such developments suggest a break on the Conservative Party's approach to dealing with Africa, there are also continuities. Noxolo suggests that the Conservative green paper for international development which formed part of the Conservative Party's 2010 election platform sought to 'champion British leadership ... through a strong invocation of empire' (Noxolo, 2012, p. 34; see also Sharp et al., 2010).

While Conservative attitudes regarding post-colonial relations had traditionally been cast in a language of continuity with an imperial past, those of Labour have been associated with a legacy of promoting development and attempting a fresh start in dealing with the developing world (Porteous, 2005; Gallagher, 2009). An important development in this new embrace of developing regions was the decision of Prime Minister Tony Blair's newly elected New Labour government in 1997 to create DFID to stand independent of the Foreign and Commonwealth Office (FCO).

Whereas Anglo-African relations as previously managed by the FCO, including aid administered by the Overseas Development Administration (ODA), were considered closely tied to Britain's national (economic and security) interests, DFID was required by law to separate its decisions about where and how to dispense aid and implement aid projects from calculations of British commercial and other national interests (Porteous, 2008; Taylor, 2010, pp. 35 - 6). The institutional influence of DFID on UK foreign policy would, according to Porteous, prove highly influential: 'DFID won over the Foreign Office, the [Ministry of Defence] and No. 10 [the Prime Minister's Office] to its view of development in Africa' (Porteous, 2005, p. 284).

This new and largely acclaimed institutional environment posed both challenges and opportunities for the incoming Conservative coalition government in 2010, even if there has been a tendency to exaggerate the accomplishments of DFID (for a more critical view on the influence of DFID, see Biccum, 2005). On one hand it had to consider how it would be possible to claim continuity with Tory tradition, while also avoiding the accusation of nostalgia for empire or the mere pursuit of commercial and national interests in foreign policy and development (Noxolo, 2012). On the other hand, there was an opportunity to seize on the fact that an older, more cynical 
conservative approach to managing (imperial) decline had been delegitimized to thereby embrace a bold transformation of the part of the Conservative Party's approach to international development. Gallagher demonstrates the degree to which New Labour had shifted the policy terrain, arguing that:

Political consensus on the Blair government's work in Africa is exceptional: from all angles of the Labour Party, the Liberal Democrats, the Conservatives - all said that, while they disagreed with the government on many other policy areas, on Africa, Blair and his colleagues had it right (Gallagher, 2009, p. 441).

The understanding was that this moment could, as the Conservative Party's 2009 Green Paper on international development suggested, constitute a win-win situation for the Conservative Party in terms of benefiting both British national interest and development in Africa (Noxolo, 2012). It would, in the words of Heppell and Lightfoot (2012, p. 132), become a matter of 'construct[ing] a post-Thatcherite electoral strategy that reflected the reshaped political terrain created by the rise of New Labour'.

However, leading Conservatives, including Rifkind and the former Secretary of State for Trade and Industry and Chair of the party's Globalization and Global Poverty Policy Group Peter Lilley, have also voiced scepticism about the separation of development policy from the direction and control of the FCO, and in particular the distinct New Labour stamp placed on DFID by its inaugural Secretary of State for International Development Clare Short (interviews with authors, London, November 2011, April 2012). According to Heppell and Lightfoot (2012, p. 136), there is likely also 'disquiet within the [Parliamentary Conservative Party] about the prioritisation given to international aid as the religious or moral dimension may not have resonated'. This even though, as McAnulla (2014, p. 467) argues, 'the belief that faith groups should be more centrally involved in shaping policies and delivering public services' did have some initial influence on how the Cameron government approached both international and domestic affairs. Rifkind notes that if a country wishes to keep military means truly exceptional it needs many ways to exert influence, and 
'cash is one' such means, in the wider context of British economic interests (interview with author, London, November 2011). The former Minister of State for Overseas Development and Africa in the Thatcher and Major governments, the Baroness Lynda Chalker, also stresses this argument. She notes that when compared to Conservative government policy before New Labour, 'ODA is not closely enough knit to the FCO... [and] you cannot work effectively in foreign policy or in development assistance without those two [departments] considering the issues together' (interview with author, London, April 2012).

That said, the Conservative-Liberal Democrat coalition government that in the 2010 elections came to succeed the New Labour government of Prime Minister Gordon Brown continued operating wholly within the existing institutional framework that identifies distinct and clearly delineated responsibilities for the FCO and DFID, as has the Conservative government continued to do since its election victory in 2015. The impact of New Labour and the institutional influence of DFID, and the ways in which the Conservative Party responded to that new environment as it readied itself for a return to government in 2010, suggest a significant blurring of the ideological and practical lines between Conservatives and Labourites in engaging with development in Africa. There is no similarly distinct conservative voice that is present and influential in shaping British policy on development in Africa in the Cameron government, as was the case in the US during the Bush administration.

\section{Conclusion}

Differences between British and American approaches in dealing with issues of African development have emerged from each country's trajectory in the post-WWII era and are somewhat paradoxical. A key difference is the way in which American conservatives actively shaped policy towards Africa, in particular through their impact on social and health policies during Bush's presidency. This active involvement is in large part a reflection of a confident and influential evangelical Christian dimension of American conservatism that has no comparable presence in the 
UK, irrespective of a modest revival during the years in opposition leading up to 2010 (Ellison, 2011, pp. 50 - 1), and in limited Christian rhetoric employed by David Cameron and some of his ministers on Britain's heritage and the 'Big Society' (McAnulla, 2014). This active engagement has emerged even though America's historical ties to and role in Africa is comparatively less significant than those of Britain (the US's significant population of African descendants notwithstanding).

By contrast British conservatives had, despite a history of empire and sentimental ties including substantial migration of Britons to settle across Africa, somewhat cynically resigned themselves to a managed decline in relations with Africa (and other former regions of the Empire) and consequent diminishing of Britain's ability to impact events on the continent (Horowitz, 1970; Murphy, 1995). When a decisive shift in British international relations arrived with New Labour and the creation of DFID, it ultimately served to further blur rather than distinguish the two major parties' approaches to international development.

While observers of US politics are fond of the notion that 'politics ends at the water's edge' (Gowa, 1998), this is actually more so the case in Britain than in the US when considering approaches to development in Africa. Moreover, the big difference is not primarily in terms of how British and American conservatives differ from their domestic ideological opponents on Africa (especially in the post-Cold War era), but rather how they differ from each other across the two countries. American conservatives have during the Bush presidency forged a distinct new approach to engaging with underdevelopment and human suffering that has no corresponding development among conservatives in Britain since the Conservative Party's return to government in 2010. This is due to the abovementioned greater degree of ideological heterogeneity within American conservatism as compared to the more coherent but also less animated brand of conservatism in Britain (Andreasson, 2014). For their African counterparts, this means that relations with Britain have remained largely a case of dealing with a familiar associate, whereas in their engagement with America it has become the case of increasingly familiarizing themselves with a new suitor. 
In the end, however, recent upheaval among both American and British conservatives will ensure significant new developments ahead. These will be driven by ideological shifts in the West as conservatives adapt to the continual transformation of international relations that has come to characterize the rise of the Global South. They will also be driven by the transformation of Africa's role in the global system and its gradual shift in external relations away from the West, however uncertain the consequences thereof (Andreasson, 2011b; Schoeman, 2011, Carmody \& Kragelund, 2016). The sense of priorities and direction of a post-Cameron leadership under Prime Minister May in Britain is only just now emerging, and the difficulty with which any Republican administration following the election of Donald Trump will engage with the world beyond its borders are telling reminders of the fact that the End of History remains forever out of reach. 


\section{References}

Amin, S. (1972). Underdevelopment and Dependence in Black Africa - Origins and Contemporary Forms. The Journal of Modern African Studies, 10(4), 503-524.

Andreasson, S. (2005). Orientalism and African development studies: the 'reductive repetition' motif in theories of African underdevelopment. Third World Quarterly, 26(6), 971-986.

Andreasson, S. (2011a). On the nature of Anglophone conservatism and its applicability to the analysis of postcolonial politics. In D. Özsel (Ed.), Reflections on Conservatism (pp. 89113). Newcastle: Cambridge Scholars Publishing.

Andreasson, S. (2011b). Africa's Prospects and South Africa's Leadership Potential in the Emerging Markets Century. Third World Quarterly, 32(6), 1165-1181.

Andreasson, S. (2014). Conservatism. In V. Geoghegan and R. Wilford (Eds.), Political Ideologies: An Introduction, $4^{\text {th }} e d$. (pp. 47-70). London: Routledge.

Andreasson, S. (2015). American and British Strategies in the Competition for Energy Resources in Sub-Saharan Africa. In S. Scholvin (Ed.), A New Scramble for Africa: The Rush for Energy Resources in Sub-Saharan Africa (pp. 13-32). Farnham: Ashgate.

Beswick, D. (2011). Aiding State Building and Sacrificing Peace Building? The Rwanda-UK relationship 1994-2011. Third World Quarterly, 32(10) 1911-1930.

Biccum, A. R. (2005). Development and the "New" Imperialism: a reinvention of colonial discourse in DFID promotional literature. Third World Quarterly, 26(6), 1005-1020.

Bond, P. (2006). Looting Africa: The Economics of Exploitation. London: Zed Books.

Bull, H. (1982). The West and South Africa. Daedalus, 111(2), 255-270.

Burkhalter, H. (2004). The Politics of AIDS: Engaging Conservative Activists. Foreign Affairs, 83(1), 8-14.

Busby, J. W. (2007). “Bono Made Jesse Helms Cry”: Jubilee 2000, Debt Relief, and Moral Action in International Politics. International Studies Quarterly, 51(2), 247-275. 
Butler, L. J. and Stockwell, S. (Eds.). (2013) The Wind of Change: Harold Macmillan and British Decolonization. Basingstoke: Palgrave Macmillan.

Carmody, P. and Kragelund, P. (2016). Who is in Charge? State Power and Agency in Sino-African Relations. Cornell International Law Journal, 49(1), 1-23.

Coker, C. (1983). Neo-conservatism and Africa: some common American fallacies. Third World Quarterly, 5(2), 283-299.

de Waal, A. (2008). The Humanitarian Carnival: A Celebrity Vogue. World Affairs, 171(2), 43-55. Dietrich, J. W. (2007). The Politics of PEPFAR: The President's Emergency Plan for AIDS Relief. Ethics \& International Affairs, 21(3), 277-292.

Duignan, P. and Gann, L. H. (1975). The Pre-colonial economies of Sub-Saharan Africa. In P. Duignan and L. H. Gann (Eds.), Colonialism in Africa 1870-1960: The Economics of Colonialism (pp. 33-67). Cambridge: Cambridge University Press.

Dunn, K. (2004). Fear of a black planet: anarchy anxieties and postcolonial travel to Africa. Third World Quarterly, 25(3), 483-499.

Dyer, J. E. (2014). The Politics of Evangelicals: How the Issues of HIV and AIDS in Africa Shaped a "Centrist" Constituency in the United States. Journal of the American Academy of Religion, 82(4), 1010-1032.

Ellison, N. (2011). The Conservative Party and the "Big Society". In C. Holden, M. Kilkey and G. Ramia (Eds.), Social Policy Review 23: Analysis and debate in social policy, 2011 (pp. $45-$ 62). Bristol: The Policy Press.

Frynas, J. G. and Paulo, M. (2007). A New Scramble for African Oil? Historical, Political, and Business Perspectives. African Affairs, 106(423), 229-251.

Gallagher, J. (2009). Healing the Scar? Idealizing Britain in Africa, 1997-2007. African Affairs, 108(432), 435-451. 
Goldstein, M. P. and Moss, T. J. (2005). Compassionate Conservatives or Conservative Compassionates? US political parties and bilateral foreign assistance to Africa. Journal of Development Studies, 41(7), 1288-1302.

Gowa, J. (1998). Politics at the Water's Edge: Parties, Voters, and the Use of Force Abroad. International Organization, 52(2), 307-324.

Heppell, T. and Lightfoot, S. (2012). "We will not balance the books on the backs of the poorest people in the world": Understanding Conservative Party Strategy on International Aid. The Political Quarterly, 83(1), 130-38.

Hofer, K. (2003). The role of Evangelical NGOs in International Development: A comparative case study of Kenya and Uganda. afrika spectrum, 38(3), 375-398.

Honderich, T. (1990). Conservatism. London: H. Hamilton.

Hook, S. W. (2008). Ideas and Change in U.S. Foreign Aid: Inventing the Millennium Challenge Corporation. Foreign Policy Analysis, 4(2), 147-167.

Horowitz, D. (1970). Attitudes of British Conservatives towards decolonization in Africa. African Affairs, 69(274), 9-26.

Huliaras, A. (2008/9). The Evangelical Roots of US Africa Policy. Survival, 50(6), 161-182.

Ikenberry, G. J. (2004). Liberalism and Empire: Logics of Order in the American Unipolar Age. Review of International Studies, 30(4), 609-630.

Kirk, R. (1995). The Conservative Mind: From Burke to Eliot, $7^{\text {th }}$ ed. Washington, DC: Regnery Publishing.

Krauthammer, C. (1990). The Unipolar Moment. Foreign Affairs, 70(1), 22-33.

Martin, W. (1999). The Christian Right and American Foreign Policy. Foreign Policy, 114(Spring), 66-80.

McAnulla, S. (2014). Cameron's Conservatism: Why God, Why Now? The Political Quarterly, $85(4), 462-470$. 
McGovern, M. (2012). Turning the Clock Back or Breaking with the Past?: Charismatic Temporality and Elite Politics in Côte D'Ivoire and the United States. Cultural Anthropology, 27(2), 239-260.

Moss, T. J. (1995). US Policy and Democratisation in Africa: The Limits of Liberal Universalism. The Journal of Modern African Studies, 33(2), 189-209.

Murphy, P. (1995). The Conservative Party and British Colonial Policy in Tropical Africa, 19511964. Oxford: Clarendon Press.

Nash, G. H. (2006). The Conservative Intellectual Movement in America: Since 1945, ThirtiethAnniversary ed. Wilmington, DE: ISI Books.

Newton, K. and Brynin, M. (2001). The National Press and Party Voting in the UK. Political Studies, 29(2), 265-285.

Noxolo, P. (2012). One world, big society: a discursive analysis of the Conservative green paper for international development. The Geographical Journal, 178(1), 31-41.

Oakeshott, M. (1962). 'On Being Conservative. In M. Oakeshott (Ed.), Rationalism in Politics: and other essays (pp. 168-196). London: Methuen \& Co.

O’Sullivan, N. (1975). Conservatism. London: J. M. Dent \& Sons.

Ovendale, R. (1995). Macmillan and the wind of change in Africa, 1957-1960. The Historical Journal, 38(2), 455-477.

Owusu, F. (2003). Pragmatism and the Gradual Shift from Dependency to Neoliberalism: The World Bank, African Leaders and Development Policy in Africa. World Development, 31(10), 1655-1672.

Porteous, T. (2005). British government policy in sub-Saharan Africa under New Labour. International Affairs, 81(2), 281-297.

Porteous, T. (2008). Britain in Africa. London: Zed Books.

Preece, R. (1980). The Anglo-Saxon Conservative Tradition. Canadian Journal of Political Science, 13(1), 3-32. 
Quinton, A. M. (1978). The Politics of Imperfection: The Religious and Secular Traditions of Conservative Thought in England from Hooker to Oakeshott. London: Faber and Faber.

Sandbrook, R. (1985). The Politics of Africa's Stagnation. Cambridge: Cambridge University Press.

Schoeman, M. (2011). Of BRICs and Mortar: The Growing Relations between Africa and the Global South. The International Spectator, 46(1), 33-51.

Sharp, J., Campbell, P. and Laurie, E. (2010). The Violence of Aid? Giving, power and active subjects in One World Conservatism. Third World Quarterly, 31(7), 1125-1143.

Stratton, A. (2010). Robert Mugabe backs David Cameron's Conservatives. The Guardian, 4 March. Available at: <www.theguardian.com/world/2010/mar/04/robert-mugabe-davidcameron-conservatives>.

Taylor, I. (2010). The International Relations of Sub-Saharan Africa. London: Continuum.

van de Walle, N. (2009). US Policy towards Africa: The Bush Legacy and the Obama Administration. African Affairs, 109(434), 1-21.

van de Walle (2015). Obama and Africa: Lots of Hope, Not Much Change. Foreign Affairs, 94(5), 54-61.

Walt, S. M. (2000). Two Cheers for Clinton's Foreign Policy. Foreign Affairs, 79(2), 63-79.

White, N. J. (2000). The business and the politics of decolonization: the British experience in the twentieth century. The Economic History Review, 53(3), 544-564.

Zeleza, P. T. (2005). Rewriting the African Diaspora: Beyond the Black Atlantic. African Affairs, 104(414), 35-68. 
Appendix: list of interviewees (positions at time of interview, and relevant previous positions)

\begin{tabular}{|c|c|}
\hline WASHINGTON (2011) & LONDON (2011 \& 2012) \\
\hline $\begin{array}{l}\text { Randall Brandt, Program and Policy Director, Program to } \\
\text { Promote and Protect America's Freedom (Senior Advisor, } \\
\text { Department of State, 2007-09) }\end{array}$ & Chris Alden, Professor, London School of Economics \\
\hline $\begin{array}{l}\text { Chester Crocker, Professor, Georgetown University } \\
\text { (Assistant Secretary of State for African Affairs, 1981-89) }\end{array}$ & $\begin{array}{l}\text { Nick Bates, Senior Research Analyst, Resource } \\
\text { Consulting Services (Senior Adviser, Department for } \\
\text { International Development) }\end{array}$ \\
\hline $\begin{array}{l}\text { Paul Fagan, Director for Africa, International Republican } \\
\text { Institute }\end{array}$ & $\begin{array}{l}\text { Sam Bowman, Director of Research, Adam Smith } \\
\text { Institute }\end{array}$ \\
\hline $\begin{array}{l}\text { Jendayi Frazer, Director, Center for International Policy \& } \\
\text { Innovation, Carnegie Mellon University (Assistant } \\
\text { Secretary of State for African Affairs, 2005-09; US } \\
\text { Ambassador to South Africa, 2004-05) }\end{array}$ & $\begin{array}{l}\text { Thomas Cargill, Assistant Head, Africa Programme, } \\
\text { Chatham House }\end{array}$ \\
\hline $\begin{array}{l}\text { Mark Green, Senior Director, U.S. Global Leadership } \\
\text { Coalition and Board Member, Millennium Challenge } \\
\text { Corporation (US Ambassador to Tanzania, 2007-09) }\end{array}$ & $\begin{array}{l}\text { Baroness Lynda Chalker, Chairman, Africa Matters Ltd. } \\
\text { (Minister of State, Foreign and Commonwealth Office, } \\
\text { 1986-1997) }\end{array}$ \\
\hline $\begin{array}{l}\text { Todd Moss, Senior Fellow, Center for Global } \\
\text { Development (Deputy Assistant Secretary, Bureau of } \\
\text { African Affairs, Department of State, 2007-08) }\end{array}$ & $\begin{array}{l}\text { Jean-Francois Drolet, Lecturer, Queen Mary, University } \\
\text { of London }\end{array}$ \\
\hline Morgan Roach, Research Assistant, Heritage Foundation & $\begin{array}{l}\text { George Grant, Director for Global Security, Henry } \\
\text { Jackson Society }\end{array}$ \\
\hline $\begin{array}{l}\text { Brett Schaefer, Fellow, Heritage Foundation Margaret } \\
\text { Thatcher Center for Freedom }\end{array}$ & Ben Harris-Quinney, Chairman, Bow Group \\
\hline $\begin{array}{l}\text { Gregory Simpkins, Staff Director, House Subcommittee } \\
\text { on Africa, Global Health and Human Rights (Vice } \\
\text { President, The Leon H. Sullivan Foundation, 2007-10) }\end{array}$ & $\begin{array}{l}\text { Peter Lilley, Member of Parliament (Secretary of State, } \\
\text { Trade and Industry, 1990-92; Chairman, Bow Group, } \\
\text { 1973-75) }\end{array}$ \\
\hline $\begin{array}{l}\text { Joel Starr, Deputy Assistant Secretary for House Affairs } \\
\text { and Foreign Relations Advisor and Counsel, Senator } \\
\text { James Inhofe (Deputy Assistant Secretary, Department of } \\
\text { State, 2007-09) }\end{array}$ & Gideon Mailer, Africa Director, Henry Jackson Society \\
\hline $\begin{array}{l}\text { Scott Taylor, Director, African Studies Program, } \\
\text { Georgetown University }\end{array}$ & Josephine Osikena, Director, Foreign Policy Centre \\
\hline $\begin{array}{l}\text { Richard Tren, Director, Africa Fighting Malaria and } \\
\text { Adjunct Fellow, Competitive Enterprise Institute }\end{array}$ & $\begin{array}{l}\text { Sir Malcolm Rifkind, Member of Parliament (Foreign } \\
\text { Secretary, 1995-97) }\end{array}$ \\
\hline $\begin{array}{l}\text { Marian Tupy, Senior Fellow, Legatum and the Cato } \\
\text { Institute }\end{array}$ & $\begin{array}{l}\text { Clare Thomas, Head of Africa Research Group, Foreign } \\
\text { and Commonwealth Office }\end{array}$ \\
\hline $\begin{array}{l}\text { Tom Woods, President, Woods International LLC } \\
\text { (Deputy Assistant Secretary of State for Africa, 2004-06; } \\
\text { Deputy Assistant Administrator, U.S. Agency for } \\
\text { International Development, 2002-04) }\end{array}$ & $\begin{array}{l}\text { Tom Young, Senior Lecturer, School of Oriental and } \\
\text { African Studies, University of London }\end{array}$ \\
\hline
\end{tabular}




\section{Notes}

${ }^{1}$ The classic approach is found in Arisotle's Politics, which provides a comparative analysis of contemporary regimes and constitutions in attempting to answer the fundamental question of how men can best live together.

${ }^{2}$ The Republican Party in the US and the Conservative Party in Britain are not synonymous with conservative ideology and politics in these two countries respectively but will where relevant be considered the effective vehicles through which conservative ideology is channeled into government policy.

${ }^{3}$ Government by the Republican Party is defined here as those years in which the US president is a Republican and/or the Republican Party constitutes a majority in both chambers of Congress (House of Representatives and Senate).

${ }^{4}$ See the Appendix for a full list of individuals interviewed, including those that have been quoted directly, and their principal positions at the time of interview.

${ }^{5}$ Although the first Cameron government from 2010 to 2015 saw the Conservative Party govern in coalition with the Liberal Democrats, all ministries relating most directly to relations with Africa, including secretaries of State (William Hague), Defence (Liam Fox and Philip Hammond) and International Development (Andrew Mitchell), were held by Conservative Party members. ${ }^{6}$ For information on Project Umubano, see http://projectumubano.com and Beswick (2011). 